\title{
Using life-history traits to explain bird population responses to changing weather variability
}

\author{
Anouk Cormont ${ }^{1,2, *}$, Claire C. Vos $^{1}$, Chris A. M. van Turnhout ${ }^{3}$, Ruud P. B. Foppen ${ }^{3}$, \\ Cajo J. F. ter Braak ${ }^{4}$ \\ ${ }^{1}$ Alterra, Wageningen UR, PO Box 47, 6700 AA Wageningen, The Netherlands \\ ${ }^{2}$ Land Use Planning Group, Wageningen University, PO Box 47, 6700 AA Wageningen, The Netherlands \\ ${ }^{3}$ SOVON, Dutch Centre for Field Ornithology, PO Box 6521, 6503 GA Nijmegen, The Netherlands \\ ${ }^{4}$ Biometris, Department of Mathematical and Statistical Methods, Wageningen UR, PO Box 100, 6700 AC Wageningen, \\ The Netherlands
}

\begin{abstract}
Bird population dynamics are expected to change in response to increased weather variability, an expression of climate change. The extent to which species are sensitive to effects of weather on survival and reproduction depends on their life-history traits. We investigated how breeding bird species can be grouped, based on their life-history traits and according to weather-correlated population dynamics. We developed and applied the linear trait-environment method (LTE), which is a modified version of the fourth-corner method. Despite our focus on single traits, 2 strategiescombinations of several traits - stand out. As expected, breeding populations of waterfowl species are negatively impacted by severe winters directly preceding territory monitoring, probably because of increased adult mortality. Waterfowl species combine several traits: they often breed at ground or water level, feed on plant material, are precocial and are generally short-distance or partial migrants. Furthermore, we found a decline in population growth rates of insectivorous long-distance migrants due to mild winters and warm springs in the year before territory monitoring, which may be caused by reduced reproduction due to trophic mismatches. We identify species that are expected to show the most significant responses to changing weather variability, assuming that our conclusions are based on causal relationships and that the way species, weather variables and habitat interact will not alter. Species expected to respond positively can again be roughly categorized as waterfowl species, while insectivorous long-distance migrants are mostly expected to respond negatively. As species traits play an important role in constructing functional groups that are relevant to the provisioning of ecosystem services, our study enables the incorporation of ecosystem vulnerability to climate change into such functional approaches.
\end{abstract}

KEY WORDS: Life-history trait - Bird population dynamics - Climate change - Linear traitenvironment method $\cdot$ LTE $\cdot$ Weather variability

Resale or republication not permitted without written consent of the publisher

\section{INTRODUCTION}

Climate change is manifested by changes in the variance of weather, with an increased frequency of extreme weather (IPCC 2001, 2007). Population dynamics of many bird species are changing in response to increased weather variability (Bolger et al. 2005, Jiguet et al. 2006, Robinson et al. 2007), presumably through impacts of weather on variation in adult survival and reproduction success (including first year survival; Robinson et al. 2007). The extent to which species are sensitive to effects of weather on survival and reproduction depends on life-history traits (Van Turnhout et al. 2010). Considering resident birds, several recent studies found relationships between adult survival and (extreme) weather circumstances during the preceding non-breeding season (temperature and snowfall; e.g. Brown \& Brown 1998, Sæether et al. 2000, Both \& Visser 2001, Sparks et al. 2002, Jones et al. 2003, Robinson et al. 2007). Mild winters and early, 
warm springs, however, have negative effects on reproduction in insectivorous migrants, because increased probability of mismatches between the timing of reproduction and the main food supply (Brown \& Brown 1998, Both \& Visser 2001, 2005, Both et al. 2006, 2009). This is especially pronounced in habitats with a seasonal food peak, such as forests (Both et al. 2010). Furthermore, population growth rates of altricial ground nesting species can be negatively impacted by a dry heat wave (Jiguet et al. 2006), and Sæther et al. (2004) reported negative effects of extreme rainfall and wind events year-round on adult survival and reproduction success of altricial species. Most of the cited studies are focused on only one or a few species and traits, and responses in population dynamics to (extreme) weather vary amongst species, habitats and geographical locations. However, Van Turnhout et al. (2010) found that population trends of 170 Dutch breeding bird species in 1990-2005 were strongly correlated with, amongst others, migration strategy, and that declines in migratory birds were associated with late arrival on the breeding grounds (see also Møller et al. 2008), suggesting that climate change is an important driver of population changes.

Impacts of enhanced weather variability on population dynamics may interfere with aims set in nature conservation programmes, which are often described in terms of the presence and abundance of target species in protected areas. In response to the emerging understanding of the impacts of climate change, researchers and policy makers (e.g. EU 2009) have called for adaptive measures to mitigate the effects of climate change on population dynamics. Therefore, there is a need for more insight into the impacts of weather variability on a broad spectrum of species. Because nature conservation is generally not based on species-specific measures, such adaptive measures demand a generalized view on responses of species (Dolédec et al. 1999). An approach that allows for the generalization and extrapolation of predictions on future performance of species (Keddy 1992) is to investigate which specific combination of life-history traits makes species sensitive to specific weather events (cf. Dolédec et al. 1999). We investigated this by examining how breeding bird species can be grouped, based on their life-history traits and according to weathercorrelated population dynamics.

The interaction between weather and life-history traits could be influenced by habitat characteristics (Karlsson \& Wiklund 2005) because of the way in which weather affects specific habitats. The same species may show different responses in different ecosystem types (Karlsson \& Van Dyck 2005, Both et al. 2010). Therefore, we analyzed possible differences between habitat types by comparing growth rate data of a broad selection of specialist and generalist species breeding in 2 ecosystem types in the Netherlands: marshlands (i.e. a mosaic of open water, reed marshes and marshland shrubs) and deciduous forests. These ecosystem types are important from a nature conservation point of view. Approximately $16 \%$ of the Netherlands has been classified as international key marshland area (Wolff 1993). Moreover, we expect marshlands and forests to differ in the way weather affects these systems. Water levels in marshlands can fluctuate strongly with precipitation amount, and can freeze over during severe winters, whereas forests are buffered against extreme weather (Stoutjesdijk \& Barkman 1992). However, forests show a more pronounced seasonal food peak, especially for insectivorous species, than marshlands, due to simultaneous leaf unfolding over the whole habitat area during spring (Both et al. 2010). This might result in higher sensitivity to mismatches in the food chain.

In exploring the relationship between population dynamics and weather, we studied changes in abundance after the occurrence of specific weather conditions. We tested the relationships between typical nest location, diet, offspring development and migration strategy of selected bird species - traits that correlated with weather conditions in other studies - and weather variables. Further arguments for using these specific traits are indicated in Table 1. As the analyzed species experienced the same weather conditions, we hypothesized that differences in their response could be attributed to different trait combinations. Instead of looking at linear population trends (cf. Both et al. 2010, Van Turnhout et al. 2010), we analyzed year-to-year changes in abundance in response to weather conditions. We developed and applied the linear trait-environment (LTE) method, which is a modified version of the fourth-corner method (Legendre et al. 1997, Dray \& Legendre 2008). Subsequently, we compared changes in the occurrence of the significant weather variables between the present climate and several climate change scenarios. This comparison gives an indication of which combination of traits and thus which species might benefit or suffer from future weather conditions.

\section{MATERIALS AND METHODS}

\subsection{Deriving yearly population indices}

We selected 77 species that annually breed in the Netherlands, of which 43 breed in marshland areas, 53 breed in forest areas and 19 breed in both marshland and forest areas (see Table S1 at www.int-res.com/ articles/suppl/c049p059_supp.pdf). Since 1984, monitoring of breeding birds in the Netherlands, organized 
Table 1. Traits used for analysis in the $\mathbf{Z}$ matrix

\begin{tabular}{|c|c|c|c|c|}
\hline Trait & $\begin{array}{l}\text { Abbre- } \\
\text { viation }\end{array}$ & Explanation (classification) & Reasoning & Source \\
\hline Nest location & lownest & $\begin{array}{l}\text { Nest location at water table, } \\
\text { along water banks or in holes } \\
\text { in the ground (1; low } \\
\text { elevations), in contrast to nest } \\
\text { locations higher in elevation } \\
\text { (0). }\end{array}$ & $\begin{array}{l}\text { Low precipitation in non- and pre-breeding } \\
\text { season leads to low water tables, which is most } \\
\text { negative for species breeding on or just above } \\
\text { water and ground level, because of low nest site } \\
\text { availability and high predation pressure } \\
\text { (Newton 1998). Extreme wind may destroy nests } \\
\text { located higher in elevation (trees and reed } \\
\text { vegetation) (Wunderle et al. 1992). A dry heat } \\
\text { wave might negatively impact ground nesting } \\
\text { species } \\
\text { (Jiguet et al. 2006). }\end{array}$ & $\begin{array}{l}\text { Cramp \& } \\
\text { Simmons } \\
(1977-1994)\end{array}$ \\
\hline \multirow[t]{4}{*}{$\begin{array}{l}\text { Main diet } \\
\text { type }\end{array}$} & fdpl & $\begin{array}{l}\text { Main food during breeding } \\
\text { season: plants (vegetative and } \\
\text { generative parts) (1; } \\
\text { herbivorous), in contrast to } \\
\text { other diets }(0) \text {. }\end{array}$ & $\begin{array}{l}\text { When temperature drops below } 5^{\circ} \mathrm{C} \text {, plant } \\
\text { growth stops, leading to reduced food } \\
\text { availability for herbivores. Temperatures below } \\
0^{\circ} \mathrm{C} \text { are negative for piscivorous species (frozen } \\
\text { water bodies) (Morgan \& Glue } 1977 \text {, Besbeas et } \\
\text { al. 2002), as well as for insectivorous species } \\
\text { (Newton 1998). Snow cover is negative for } \\
\text { ground feeders (insectivorous species and } \\
\text { herbivores) (Peach et al. 1995). Low water tables } \\
\text { during both non-breeding and breeding seasons } \\
\text { are negative to piscivorous species (Den Held } \\
\text { 1981). Warmth in spring and summer is positive } \\
\text { for insectivorous species, because of high insect } \\
\text { abundance (Birch 1953). In combination with } \\
\text { drought, warmth is expected to negatively affect } \\
\text { herbivorous species through food shortages } \\
\text { (Newton 1998). }\end{array}$ & $\begin{array}{l}\text { Cramp \& } \\
\text { Simmons } \\
(1977-1994)\end{array}$ \\
\hline & fdinvert & $\begin{array}{l}\text { Main food during breeding } \\
\text { season: insects }(1 ; \text { insecti- } \\
\text { vorous), in contrast to other } \\
\text { diets }(0) .\end{array}$ & & \\
\hline & fdpisci & $\begin{array}{l}\text { Main food during breeding } \\
\text { season: fish (1; piscivorous), in } \\
\text { contrast to other diets }(0) \text {. } \\
\text { Trait occurs only for } \\
\text { marshland species. }\end{array}$ & & \\
\hline & fdmeat & $\begin{array}{l}\text { Main food during breeding } \\
\text { season: small mammals }\left(1_{i}\right. \\
\text { raptors), in contrast to other } \\
\text { diets }(0) \text {. }\end{array}$ & & \\
\hline $\begin{array}{l}\text { Offspring } \\
\text { development }\end{array}$ & altr & $\begin{array}{l}\text { Altricial species (1) that are } \\
\text { nidicolous and hatched } \\
\text { without feathers, in contrast to } \\
\text { precocial species }(0) \text { that are } \\
\text { nidifugous and hatched with } \\
\text { feathers. }\end{array}$ & $\begin{array}{l}\text { Extreme rainfall and wind events during the } \\
\text { breeding season are most negative for precocial } \\
\text { species that often lack shelter in a nest, in } \\
\text { contrast to altricial species (Sæther et al. 2004). A } \\
\text { dry heat wave might negatively impact altricial } \\
\text { species (Jiguet et al. 2006). }\end{array}$ & $\begin{array}{l}\text { Cramp \& } \\
\text { Simmons } \\
(1977-1994)\end{array}$ \\
\hline \multirow[t]{3}{*}{$\begin{array}{l}\text { Migration } \\
\text { strategy }\end{array}$} & resid & $\begin{array}{l}\text { Migration strategy: resident } \\
\text { (1) during winter, in contrast } \\
\text { to other strategies }(0) \text {. }\end{array}$ & $\begin{array}{l}\text { Mild winters are most beneficial for sedentary } \\
\text { birds because of high winter survival. For long- } \\
\text { distant migrants, mild winters will have either a } \\
\text { neutral effect, because they are away on the } \\
\text { wintering grounds, or a negative effect, due to } \\
\text { competition with residents for resources and } \\
\text { occurrence of mismatches (Newton 1998). Early } \\
\text { warm spring temperatures are negative for } \\
\text { (long-distance) migrants because of the } \\
\text { increased probability of food mismatches (Both \& } \\
\text { Visser 2001, 2005, Both et al. 2006). }\end{array}$ & $\begin{array}{l}\text { Speek \& } \\
\text { Speek } \\
(1984), \\
\text { Wernham } \\
\text { et al. (2002) }\end{array}$ \\
\hline & pmigr & $\begin{array}{l}\text { Migration strategy: partial } \\
\text { migrant/short-distance } \\
\text { migrant (1) during winter, in } \\
\text { contrast to other strategies }(0) \text {. }\end{array}$ & & \\
\hline & migr & $\begin{array}{l}\text { Migration strategy: long } \\
\text { distance migrant (1) during } \\
\text { winter, in contrast to other } \\
\text { strategies }(0) \text {. }\end{array}$ & & \\
\hline
\end{tabular}


by SOVON Dutch Centre for Field Ornithology and Statistics Netherlands, is based on the method of territory mapping in fixed study plots (Bibby et al. 1997, Van Turnhout et al. 2010). Between March and July, study plots (10 to 500 ha each) are visited 5 to 10 times. Size of study plots, as well as number, timing and duration of visits, depend on habitat type and species selection. All birds with behaviour indicative of a territory (e.g. song, pair bond, display, alarm and nests) are recorded on field maps. Species-specific interpretation criteria are used to determine the number of territories at the end of the season. Fieldwork and interpretation methods are standardized and described in detail (Van Dijk 2004, Van Dijk et al. 2004). For the selected species, abundances per habitat type are presented as yearly indices; for each of the 19 species that breed in both marshland and forest areas, 2 indices are available. Indices are calculated using TRIM software (Pannekoek \& Van Strien 2005), based on log-linear Poisson regression. Indices are presented using 1990 as a base year (index $=100$ ). Log ratios of subsequent yearly values of indices $\left(\ln \left[\right.\right.$ index $_{\text {species } \__{-} \text {, year__ } t}$ ' index $\left._{\text {species_ } i \text {, year } \_t-1}\right]$ ) are used in our analyses and correspond to yearly population growth rates of the species on log scale. Because weather influences population growth via reproduction and mortality rates, population growth rate is a proper index to describe population dynamics. We used index values from 1984 to 2005 .

\subsection{Deriving weather variables}

The Royal Netherlands Meteorological Institute (KNMI) acquires weather data according to the standards of the World Meteorological Organization. The KNMI administers ca. 35 weather stations and 54 wind stations throughout the Netherlands, of which the De Bilt station is located in the centre of the country. Weather data acquired from this station are representative for the mean climate conditions in the Netherlands (Van Oldenborgh \& Van Ulden 2003), except for wind speeds, which differ too much spatially (generally higher wind speeds along the North Sea coast). We obtained data on mean daily temperatures and wind speeds, as well as total daily precipitation, precipitation duration, snowfall and occurrence of thunderstorms, from KNMI for the period 19842005. From these we calculated 12 weather variables that describe the weather in the breeding and nonbreeding seasons (Table 2). For wind speeds, values were derived from data from all meteorological stations in the Netherlands; the remaining weather variable values were derived from the De Bilt meteorological station.
Table 2. Weather variables used for analysis in the $\mathbf{X}$ matrix. NB: non-breeding season; B: breeding season. Data were derived from the De Bilt meteorological station (except for data from B_squall, which were derived from all meteorological stations in the Netherlands). All weather variable values were logtransformed $(\ln [x+1]$, and $\ln [x+5]$ for NB_tempcold-month), except values for B_temp and B_tempaprmay; (-) unitless

\section{Abbreviation \\ Explanation (units)}

NB_IJnsen

IJnsen value (IJnsen 1981) ranging from 0 to 60 (-), expressing winter severity; the higher the value, the more severe the winter. Calculation: $\left(v^{2} / 363\right)+(2 y / 3)+$ $(10 z / 9)$, where $V, y$ and $z$ are the number of $24 \mathrm{~h}$ periods with Tmin $<0^{\circ} \mathrm{C}$, Tmax $<0^{\circ} \mathrm{C}$ and Tmax $<-10^{\circ} \mathrm{C}$, respectively, during the period November-March.

NB_tempcoldmonth

Tmean of the coldest month $\left({ }^{\circ} \mathrm{C}\right)$; for each year, the Tmean of each month from October to March was calculated and the coldest monthly average was taken.

NB_frostdays

Longest duration of consecutive days (-) with daily Tmean $<0^{\circ} \mathrm{C}$.

NB_rain

Total precipitation sum over the non-breeding season (mm).

NB_snowdays

Longest duration of consecutive days (-) with snow cover $\geq 2 \mathrm{~cm}$.

B_temp

Tmean $\left({ }^{\circ} \mathrm{C}\right)$

B_tempaprmay

Tmean $\left({ }^{\circ} \mathrm{C}\right)$ from 16 April to 15 May.

B_rain

Total precipitation sum over breeding season (mm).

B_heavyraindays

Longest duration of consecutive days (-) with daily average precipitation sum $>3 \mathrm{~mm}$.

B_drydays

Longest duration of consecutive days (-) with daily precipitation sum $<1 \mathrm{~mm}$ (Robinson et al. 2007).

B_squall

Total number of squalls (-) (wind speed $>22$ knots $\left(11.31 \mathrm{~m} \mathrm{~s}^{-1}\right)$ and lasting for at least $1 \mathrm{~min}$.

B_heatwave

Number of days comprising a heat wave (-). For the Netherlands, a heat wave is defined as a period of at least 5 consecutive days in which Tmax $>25^{\circ} \mathrm{C}$, provided that on at least $3 \mathrm{~d} \operatorname{Tmax}>30^{\circ} \mathrm{C}$ (Meehl \& Tebaldi 2004).

Weather variables that impact population dynamics through adult mortality will change numbers of territories immediately. Changes in population dynamics due to a weather event affecting recruitment rates (reflecting reproductive success and first winter survival) will become noticeable in territory numbers $1 \mathrm{yr}$ after the occurrence of the weather event, especially for species 

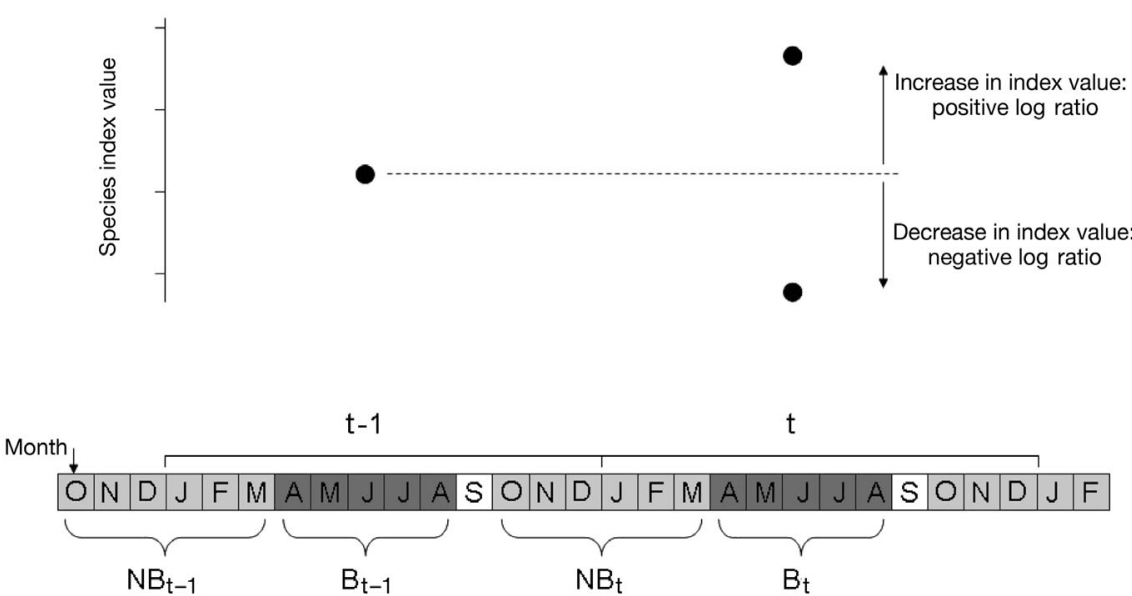

Fig. 1. Timing of territory monitoring $(\bullet)$ and periods of occurrence of weather variables in 2 subsequent years, $t-1$ and $t$. An increase in the index value between $t-1$ and $t$ results in positive population growth rate, and vice versa. NB: nonbreeding season (October-March); B: breeding season (April-August)

that are able to reproduce 1 yr from hatching. Therefore, we derived values for weather variables that occurred during the non-breeding or winter season (NB; from October to March) and the breeding season (B; from April to August; see supplement Fig. S1). We related weather variable values of current years $(t)$ and previous years $(t-1 ; 1$ yr before territory monitoring) to population growth rates (Fig. 1). Weather in the non-breeding season of the previous year (NBt-1) can affect species condition and, eventually, reproductive success (carry-over effects; Norris \& Taylor 2006). Reproductive success in the breeding season of the previous year $(\mathrm{B} t-1)$ will affect population numbers in the breeding season of the current year $(\mathrm{B} t)$. Adult mortality in the non-breeding and breeding seasons of the current year (NBt and $\mathrm{B} t$ ) will also affect population numbers in the breeding season of the current year $(\mathrm{B} t)$.

Weather variables indicating winter severity (IJnsen, mean temperature of the coldest month and longest duration of consecutive frost days) are strongly correlated (see supplement Table S2). Mild winters are often rainy - relatively high winter temperatures and precipitation are supplied by west winds from the North Sea (Van Oldenborgh \& Van Ulden 2003) — and are frequently followed by a warm spring and breeding season (van den Dool \& Nap 1981). Moreover, in the period 1984-2005, warm breeding seasons were often followed by mild winters, and a rainy winter was frequently followed by another rainy (but not necessarily a mild) winter. The number of days comprising a heat wave is positively correlated to the mean temperature of the breeding season. Correlations between weather variables will not affect the analysis because each weather variable is tested separately. However, it may affect the interpretation of the results and hamper inferences (see Section 4).

\subsection{Selecting traits}

We selected 4 traits that correlate with population dynamics in response to weather circumstances. For each species, the following categorical traits were considered: (1) nest location: low elevations (at water table, along water banks or in holes in the ground) vs. higher elevations; (2) main diet type (food during breeding season consists of plant material vs. insects vs. fish vs. mammals); (3) offspring development (altricial vs. precocial); and (4) migration strategy (resident vs. partial migrant vs. long-distance migrant). These traits are used in the analysis with the LTE method. Data sources for trait values, classifications and references are indicated in Table 1.

\subsection{LTE method}

The LTE method relates a species trait $(z)$ to an environmental variable $(x)$ via data on (change in) abundance of the set of species in a set of sites. Here, sites are years, the environmental variable is an annual weather variable and year-to-year change in abundance or growth rate is derived for the selection of breeding birds. To introduce LTE, we start with a 2-step analysis: (1) Regressions of the growth rate values to each weather variable give a species-specific regression coefficient $b_{k}$, where $k$ is the species; (2) these regression coefficients are correlated to each trait. LTE integrates both steps in a single model (Fig. 2). LTE, described in detail in Supplement 1, achieves this integration on the basis of a linear model with main effects for the weather variable and the trait and their interaction. The interaction between trait and weather variable in this model captures the traitweather relationship, in particular the trait-dependent effect of weather on the population growth rate. We tested the significance of this interaction by a permutation test. In Supplement 1, we compare LTE and permutation test with fourth-corner analysis (Legendre et al. 1997, Dray \& Legendre 2008), which is a method of trait-environment analysis designed primarily for presence-absence data. We performed separate analyses for marshland birds and for forest birds and we report correlation coefficients, statistics on the $b_{k}$ and 
the results of the significance tests, obtained from the LTE function that we wrote in R 2.9.0 software (Ihaka \& Gentleman 1996).

To obtain first insight into the clustering of species against their traits, we performed a separate ordination of the traits (Z matrix) in addition to the LTE analyses. This principal components analysis (PCA) was conducted with CANOCO (Ter Braak \& Šmilauer 2002), providing an optimal ordination of species and traits.

\section{RESULTS}

The PCA and LTE analyses show that in marshland birds one distinct group of species that shares a specific combination of traits stands out: waterfowl species that often breed at ground or water level, feed on plant material, are precocial and generally do not migrate over long distances. These traits are correlated (Fig. 3a and Table S3). As expected, these waterfowl are negatively impacted by severe winters directly preceding territory monitoring during the breeding season, and benefit from mild, rainy winters (see Table 3 for results on marshland birds). Moreover, the analyses show a decline in population growth rates of altricial marshland species that do not breed at ground level and feed on sources other than plant material (especially insects) that is correlated with warm springs in the year preceding territory monitoring. Our results do not
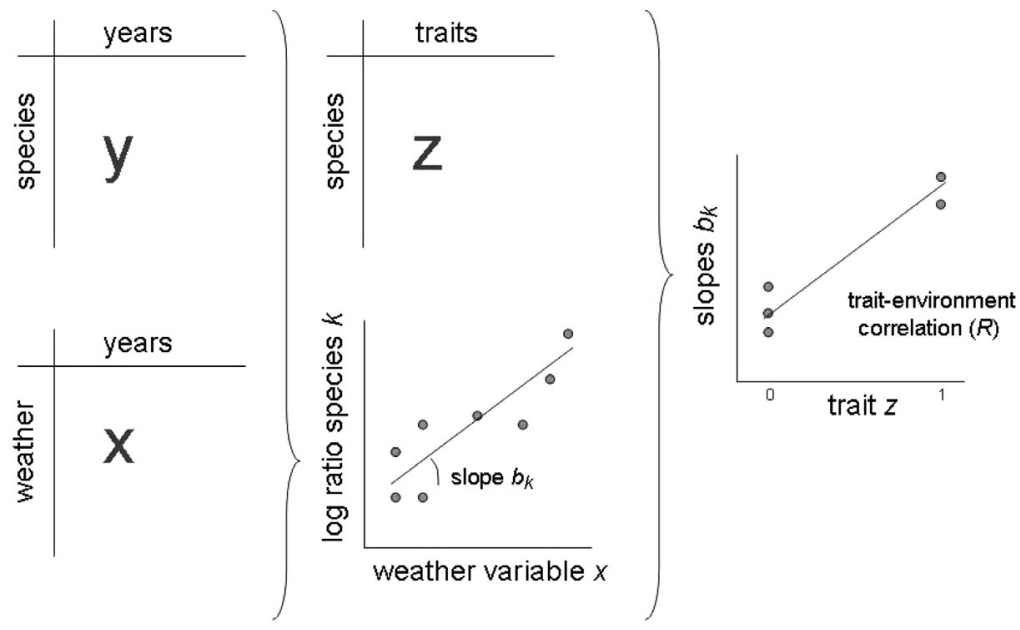

Fig. 2. Schematic overview of the linear trait-environment (LTE) analysis procedure. Species-specific regression coefficients $\left(b_{k}\right)$ are obtained from regressions of the population growth rate values (Y matrix) vs. each weather variable ( $\mathbf{X}$ matrix). Subsequently, the species-specific regression coefficients are correlated to each trait $z$ ( $\mathbf{Z}$ matrix). $\mathrm{R}$ is the Pearson correlation between the trait $z$ and the species-specific regression coefficients $b_{k}$, with $\mathrm{R}^{2}$ being the fraction of the environmentally structured variation that can be explained by the trait. When both regressions (regression population growth rates vs. weather variable and regression $b_{k}$ values vs. trait) are significant, we report a trait-environment relationship indicate a relationship between growth rates of altricial species and heat waves or rain storm events. In addition to our expectations, we found other correlations between life-history traits and weather-correlated variation in growth rate: (1) migratory marshland species that do not breed at ground level and are often altricial benefit from severe winters; (2) waterfowl species are negatively impacted by long snow cover duration in the year preceding territory monitoring; (3) waterfowl species benefit from a warm spring in the year before territory monitoring (April-May), whereas residential marshland species benefit from a warm breeding season.

In forest birds, one distinct group of species also stands out: long-distance migrants that are often insectivorous or feed insects to their juveniles (see Fig. 3b and Table S3 for results on forest birds) show an increase in population growth rates following severe winters and cold springs (April-May), and a decline in population growth rates following mild winters and warm springs in the year before territory monitoring (Table 3). Our results do not indicate a negative impact of cold and snowy winters. Neither can we distinguish a negative impact of heat waves or rain storm events on growth rates of altricial (low nesting) species. However, we found a few other correlations between lifehistory traits and weather-correlated variation in growth rates for forest species. Carnivorous and residential species show a decline in population growth rates that is correlated with severe, dry winters in the year before territory monitoring. Partial or short-distance migrants are negatively impacted by severe winters directly preceding territory monitoring and by high precipitation sums over the breeding season when territories are counted. Partial migrants profit from rainy breeding seasons in the year before territory monitoring, whereas carnivorous and other non-insectivorous species are negatively impacted by high precipitation over the breeding seasons. Migrants, however, profit from these weather circumstances.

\section{DISCUSSION}

\subsection{Responses due to traits}

We investigated how bird species can be grouped according to weather-correlated population dynamics based on their lifehistory traits. Despite our focus on single traits, 2 strategies (traits that jointly appear in bird species) stand out. We have shown 

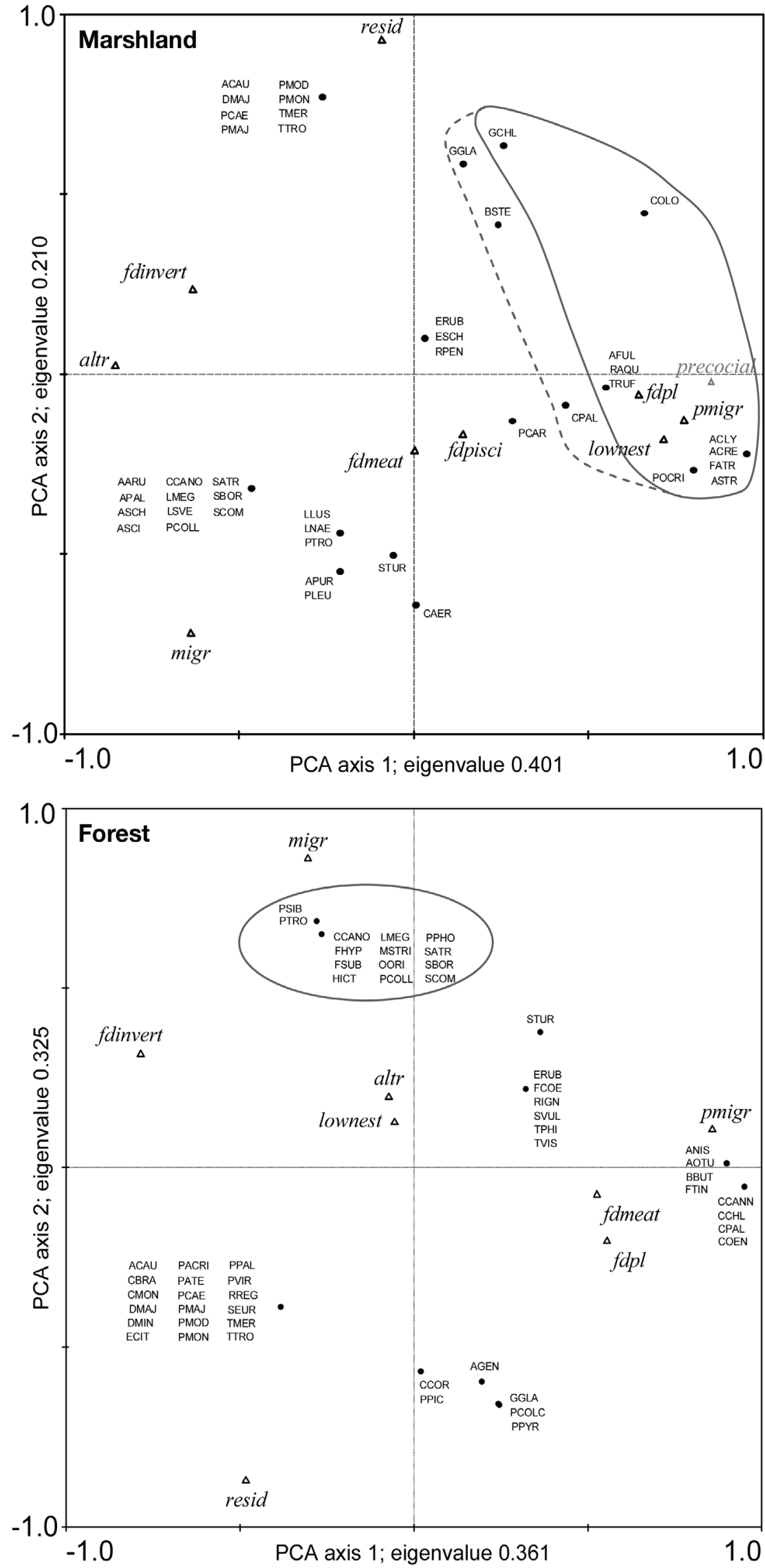

that, in general, waterfowl that breed at ground or water level, feed on plant material, are precocial and do not migrate over long distances are negatively impacted by severe winters. This is probably a result of increased adult mortality (e.g. Bibby 1981). Furthermore, a decline in population growth rates of insectivorous long-distance migrants as a result of mild winters and warm springs in the year before territory monitoring may be caused by reduced reproduction success. When these species arrive relatively late from the wintering grounds after mild winters, mismatches can occur between the timing of reproduction and the food supply to the juveniles. Competition with residents that survived the mild winter in high numbers could be another cause for reduced reproductive success of migrants.

As we interpret our data, juvenile survival in Year $t-1$ and adult survival in Year $t$ of residential marshland and waterfowl species increase due to a warm spring and breeding season. This can probably be explained by increased food availability during a warm spring. However, the increased chance for juveniles to survive their first year until the next breeding season-the moment of territory monitoring - can also be caused by a mild winter, often following a warm breeding season (Morgan \& Glue 1977, Besbeas et al. 2002).

We see remarkable differences as well as similarities in comparing the results between marshland and forest species (Table 3). Both marshland and forest species respond to winter severity. Nest location and Offspring development are important traits for marshland species in this respect, but not for forest species. This is probably because almost all forest species breed in trees and are altricial. Hence, the variation amongst the traits

Fig. 3. Ordination of marshland and forest species and traits, resulting from the principal components analysis (PCA). Encircled are waterfowl sensu strictu (dashed: sensu lato; jay, bittern and wood pigeon cannot be classified as waterfowl, but share most traits and responses) and insectivorous long-distance migrants. For abbreviations of species names, see Table $\mathrm{S} 1$; for abbreviations of traits, see Table 1 
Table 3. Relationships between traits and weather variables for marshland and forest species, expressed by significance, traitweather correlation and mean species-specific regression coefficients resulting from the linear trait-environment (LTE) analysis for different trait categories. Significant relationships are shown. n: number of species; p: statistical significance for trait-environment relationship; R: Pearson correlation between the trait $z$ and the species-specific regression coefficients $b_{k}$ obtained from regressions of population growth rate values on indicated weather variables; $b_{k}$ mean: mean of $b_{k}$ values of species that do not hold the trait (trait $=0$ ) or that hold the trait (trait $=1$ ); $b_{k}$ quartiles: 25 th and 75 th percentiles of $b_{k}$ values

\begin{tabular}{|c|c|c|c|c|c|c|c|c|}
\hline Trait & $\begin{array}{l}\text { Abbreviation } \\
\text { ( } \mathrm{n} \text { trait } 0 ; \mathrm{n} \text { trait } 1\end{array}$ & Variable & $\mathrm{p}$ & $\mathrm{R}$ & $\begin{array}{c}b_{k} \text { mean } \\
(\text { trait }=0)\end{array}$ & $\begin{array}{c}b_{k} \text { quartiles } \\
(\text { trait }=0)\end{array}$ & $\begin{array}{c}b_{k} \text { mean } \\
(\text { trait }=1)\end{array}$ & $\begin{array}{c}b_{k} \text { quartiles } \\
(\text { trait }=1)\end{array}$ \\
\hline \multicolumn{9}{|c|}{ Marshland species } \\
\hline \multirow[t]{6}{*}{ Nest location } & \multirow[t]{6}{*}{ lownest $(28 ; 15)$} & NB_IJnsen & 0.042 & -0.348 & 0.019 & $-0.016,0.071$ & -0.036 & $-0.083,0.014$ \\
\hline & & NB_tempcoldmonth & 0.013 & 0.407 & -0.035 & $-0.085,0.02$ & 0.065 & $-0.019,0.136$ \\
\hline & & NB_frostdays & 0.043 & -0.384 & 0.017 & $-0.007,0.057$ & -0.032 & $-0.082,0.012$ \\
\hline & & NB_rain & 0.023 & 0.335 & -0.066 & $-0.173,-0.01$ & 0.123 & $-0.041,0.21$ \\
\hline & & NB_snowdays $t-1$ & 0.011 & -0.628 & 0.023 & $0.002,0.052$ & -0.043 & $-0.088,-0.005$ \\
\hline & & B_tempaprmay $t-1$ & 0.005 & 0.628 & -0.012 & $-0.026,-0.001$ & 0.023 & $0.005,0.042$ \\
\hline \multirow{2}{*}{$\begin{array}{l}\text { Main diet } \\
\text { type }\end{array}$} & \multirow[t]{2}{*}{ fdpl $(35 ; 8)$} & NB_snowdays $t-1$ & 0.035 & -0.421 & 0.010 & $-0.011,0.039$ & -0.045 & $-0.096,0.008$ \\
\hline & & B_tempaprmay $t-1$ & 0.044 & 0.392 & -0.005 & $-0.018,0.009$ & 0.022 & $0,0.054$ \\
\hline \multirow{6}{*}{$\begin{array}{l}\text { Offspring } \\
\text { development }\end{array}$} & \multirow{6}{*}{ altr $(10 ; 33)$} & NB_IJnsen & 0.035 & 0.380 & -0.052 & $-0.085,0.005$ & 0.016 & $-0.027,0.059$ \\
\hline & & NB_tempcoldmonth & 0.010 & -0.447 & 0.094 & $-0.01,0.165$ & -0.029 & $-0.079,0.027$ \\
\hline & & NB_frostdays & 0.047 & 0.430 & -0.048 & $-0.085,0$ & 0.014 & $-0.013,0.055$ \\
\hline & & NB_rain & 0.040 & -0.305 & 0.149 & $-0.009,0.212$ & -0.045 & $-0.164,0.022$ \\
\hline & & NB_snowdays $t-1$ & 0.009 & 0.683 & -0.063 & $-0.098,-0.026$ & 0.019 & $0,0.046$ \\
\hline & & B_tempaprmay $t-1$ & 0.010 & -0.678 & 0.033 & $0.017,0.052$ & -0.010 & $-0.019,0.004$ \\
\hline \multirow{4}{*}{$\begin{array}{l}\text { Migration } \\
\text { strategy }\end{array}$} & \multirow[t]{2}{*}{ resid $(31 ; 12)$} & B_temp $t-1$ & 0.037 & 0.373 & -0.016 & $-0.035,0.015$ & 0.042 & $0.022,0.082$ \\
\hline & & B_tempaprmay & 0.040 & 0.308 & -0.007 & $-0.017,0.004$ & 0.018 & $-0.001,0.037$ \\
\hline & \multirow[t]{2}{*}{$\operatorname{migr}(25 ; 18)$} & NB_tempcoldmonth & 0.026 & -0.351 & 0.035 & $-0.036,0.108$ & -0.048 & $-0.089,-0.002$ \\
\hline & & NB_frostdays & 0.044 & 0.366 & -0.019 & $-0.07,0.02$ & 0.026 & $-0.004,0.056$ \\
\hline \multicolumn{9}{|l|}{ Forest species } \\
\hline \multirow{8}{*}{$\begin{array}{l}\text { Main diet } \\
\text { type }\end{array}$} & \multirow[t]{4}{*}{ fdinvert $(50 ; 38)$} & NB_IJnsen $t-1$ & 0.014 & 0.380 & -0.029 & $-0.054,0.009$ & 0.011 & $-0.022,0.046$ \\
\hline & & NB_tempcoldmonth $t-1$ & 0.027 & -0.369 & 0.038 & $0.009,0.06$ & -0.015 & $-0.042,0.032$ \\
\hline & & NB_frostdays $t-1$ & 0.030 & 0.379 & -0.023 & $-0.053,0$ & 0.009 & $-0.014,0.033$ \\
\hline & & B_rain & 0.016 & 0.359 & -0.088 & $-0.138,0$ & 0.035 & $-0.051,0.113$ \\
\hline & \multirow[t]{4}{*}{ fdmeat $(48 ; 5)$} & NB_IJnsen $t-1$ & 0.006 & -0.557 & 0.009 & $-0.022,0.038$ & -0.082 & $-0.078,-0.058$ \\
\hline & & NB_frostdays $t-1$ & 0.015 & -0.591 & 0.007 & $-0.014,0.033$ & -0.070 & $-0.073,-0.059$ \\
\hline & & NB_rain $t-1$ & 0.017 & 0.511 & -0.022 & $-0.082,0.038$ & 0.211 & $0.086,0.37$ \\
\hline & & B_rain & 0.008 & -0.539 & 0.027 & $-0.057,0.089$ & -0.257 & $-0.366,-0.157$ \\
\hline \multirow{14}{*}{$\begin{array}{l}\text { Migration } \\
\text { strategy }\end{array}$} & \multirow[t]{3}{*}{ resid $(29 ; 24)$} & NB_IJnsen $t-1$ & 0.019 & -0.332 & 0.014 & $0.005,0.047$ & -0.017 & $-0.032,0.001$ \\
\hline & & NB_tempcoldmonth $t-1$ & 0.027 & 0.331 & -0.020 & $-0.054,0.021$ & 0.024 & $0.008,0.049$ \\
\hline & & NB_frostdays $t-1$ & 0.019 & -0.348 & 0.012 & $-0.005,0.047$ & -0.015 & $-0.031,0.005$ \\
\hline & \multirow[t]{5}{*}{ pmigr $(39 ; 14)$} & NB_IJnsen & 0.007 & -0.403 & 0.015 & $-0.002,0.05$ & -0.041 & $-0.088,0.011$ \\
\hline & & NB_tempcoldmonth & 0.003 & 0.412 & -0.022 & $-0.068,0.012$ & 0.061 & $-0.011,0.114$ \\
\hline & & NB_frostdays & 0.012 & -0.344 & 0.011 & $-0.009,0.044$ & -0.032 & $-0.066,0.009$ \\
\hline & & B_rain $t-1$ & 0.032 & 0.328 & -0.031 & $-0.107,0.024$ & 0.088 & $-0.034,0.186$ \\
\hline & & B_rain & 0.042 & -0.323 & 0.030 & $-0.061,0.121$ & -0.083 & $-0.067,0.011$ \\
\hline & \multirow[t]{6}{*}{$\operatorname{migr}(38 ; 15)$} & NB_IJnsen $t-1$ & 0.001 & 0.579 & -0.017 & $-0.033,0.008$ & 0.044 & $0.023,0.058$ \\
\hline & & NB_tempcoldmonth $t-1$ & 0.003 & -0.524 & 0.022 & $-0.008,0.042$ & -0.055 & $-0.089,-0.011$ \\
\hline & & NB_frostdays $t-1$ & 0.001 & 0.611 & -0.015 & $-0.028,0.007$ & 0.037 & $0.03,0.052$ \\
\hline & & NB_rain $t-1$ & 0.018 & -0.412 & 0.034 & $-0.03,0.058$ & -0.087 & $-0.149,-0.036$ \\
\hline & & B_tempaprmay $t-1$ & 0.040 & -0.358 & 0.005 & $-0.002,0.013$ & -0.013 & $-0.024,0.007$ \\
\hline & & B_rain & 0.005 & 0.462 & -0.045 & $-0.104,0.025$ & 0.113 & $0.013,0.205$ \\
\hline
\end{tabular}


Nest location and Offspring development is relatively low (see Fig. 3b) and these traits do not affect the sensitivity to winter severity in forest birds.

Marshland and forest long-distance migrants differ in their response to winter severity and spring temperature in terms of timing ( $t$ and $t-1$, respectively). Our findings on long-distance migrants in forests that are negatively impacted by mild winters and warm springs in the year before territory monitoring are in agreement with those of Both \& Visser $(2001,2005)$ and Both et al. $(2006,2010)$. Both et al. (2010) showed mismatches between timing of food requirements and food availability for long-distance migrants, but only in habitats with a seasonal food peak, such as forests. The correlations Both et al. $(2006,2010)$ used were based on linear trends over a 20 yr time span. We analyzed population trend data in a different way, looking at year-to-year variation, using the (positive or negative) population growth rate between subsequent years. In agreement with the long-term trend analyses of Both et al. $(2006,2010)$, we showed that the impact on population dynamics of long-distance migrants is not immediate but delayed by $1 \mathrm{yr}$. This indicates, as hypothesized by Both et al. $(2006,2010)$, that early springs result in a low breeding success, consequently followed by a lower population size $1 \mathrm{yr}$ later. This is in further support of the mismatch hypothesis. In contrast to Both et al. (2006, 2010), we also found an effect of winter severity, which is strongly correlated to spring temperatures, on longdistance migrants in marshland habitat. This is difficult to interpret. Winter conditions are correlated with population size in the following breeding season, suggesting an immediate response. This indicates effects on survival, e.g. lower survival rates for long-distance migrants after mild winters. But this seems quite unlikely because these migrants are in their distant winter quarters. One can only speculate about the true causal relationship. It might result from impact on food resources or interspecific competition pressures. After a severe winter, the population size of sedentary species is low, thus allowing a higher population size of migrants to settle (Lemoine et al. 2007). In contrast with the forest bird community in which most of the migrants are passerines and insectivores, the migrant marshland bird community is more diverse. This and the year-to-year approach could explain the difference with the findings of the Both et al. $(2006,2010)$ studies, which were based on long-term trend estimates and dealt with a restricted species set (only passerines).

For long-distance migrants, there might be other constraints en route to or at the wintering grounds that could additionally impact population fluctuations (Newton 2004, Sanderson et al. 2006), which are not taken into account by considering only Dutch weather variables. In particular, species wintering in the Sahel have shown strong declines in breeding population numbers during severe droughts in the 1970s and 1980s (Foppen et al. 1999, Zwarts et al. 2009). However, these effects are not likely to change our results, considering responses to weather on the breeding grounds. Conditions during the breeding season in the Netherlands - which the Dutch populations of long-distance migrants share-correlate unambiguously to population fluctuations of most of these species, and their responses adequately match the expectations we formulated in Table 1 on the basis of recent literature.

Marshland species respond to snow cover duration, whereas forest species do not. This difference can be attributed to the fact that marshland systems are open and can become totally covered with snow. Especially in combination with temperatures below the freezing point, long-lasting snow cover can be detrimental to waterfowl species foraging on terrestrial plant material (e.g. agricultural managed grasslands) that is then covered with snow (see Fig. 3a; waterfowl clustered near main diet type of plants).

Neither marshland nor forest species respond to heat waves and dry periods. This is in contrast to the results of Jiguet et al. (2006), who found a response in population growth rates to the 2003 French heat wave, an exceptionally hot and dry 6 mo period. In the Netherlands, only 9 heat waves occurred over the period 1984-2005, with a mean duration of $9 \mathrm{~d}$. These heat waves were probably not experienced as harmful by the species. Moreover, the longest duration of dry days during the breeding season over the period 1984-2005 was 28 d, which occurred in both 1995 and 2003. Again, these dry periods were probably not experienced as exceptionally long by the species. Furthermore, events such as droughts, heavy rain and squalls often occur at a local scale, and effects of these events on population dynamics can be leveled off in national population trends.

The main assumption in our study is that species differ in their responses to weather, and that these responses can be attributed to different trait combinations. We used a data set on a large number of species counted in the same (biogeographical) region over the same set of years. Population changes may be correlated to other causal factors operating in the same years and region that are not covered by our explanatory variables. However, we expect that on such temporal and spatial scales, weather will be an important explanatory factor in year-to-year population changes, taking into account the numerous studies that found evidence for the impact of weather on bird vital rates (e.g. Sæther et al. 2004, Both et al. 2006). 


\subsection{LTE method}

We chose not to explicitly take account of differences in accuracy in the index values (derived from TRIM), except by taking logarithms and by excluding rare species, for which the indices are more error prone. By trying to take account of differences in accuracy, the simplicity of the method would be lost. We think that the permutation approach is robust to any differences. Moreover, if the errors associated with the LTE model are large compared with those in the (log) indices, it is close to optimal not to take into account the differences in accuracy.

Autocorrelation in time series may lead to spurious cross-correlations; a standard cure is pre-whitening. We diminished the autocorrelation in yearly indices by analyzing the log ratio of subsequent values. The resulting lag-1 autocorrelations are mostly slightly negative (in absolute value, $75 \%$ are smaller than 0.3 and the maximum is 0.55 ). The lag-1 autocorrelations in the weather variables are even smaller in size. The values are too small to invalidate our analysis and the series are too short to account in a more elaborate way for autocorrelation. Ranta et al. (2000) warn that it can be very hard to detect environmental forcing of population dynamics if the dynamics is not stable. However, they argue that slowly growing species such as birds show mostly stable dynamics and 'are likely to respond to climatic variability in a straightforward way' (Ranta et al. 2000, p. 1855). As a consequence, the method of our study works for birds, but may fail to detect environmental forcing for rapidly multiplying organisms.

\subsection{Implications of future weather conditions}

We extrapolated the observed correlations to future weather conditions predicted by climate change models. By doing so, we assume that these correlations are based on causal relationships, and that the way in which species, weather variables and habitat types interact will not alter in the future. From KNMI data on future daily temperatures and precipitation sums (http://climexp.knmi.nl/Scenarios_monthly/), we calculated future values for weather variables affecting species population dynamics (Fig. 4). We used KNMI scenarios $\mathrm{W}$ and $\mathrm{W}^{+}$, which assume an average global temperature rise of $2^{\circ} \mathrm{C}$ from 1990 to 2050, and an increased occurrence of mild wet winters and warm dry summers for the $\mathrm{W}^{+}$scenario (see www.knmi.nl/ research/climate_services/). Climate change is likely to be manifested by fewer cold and frost days (IPCC 2001, 2007), and hence by more frequent mild winters (Fig. 4A) and warm springs (Fig. 4C). Based on our results, we hypothesize that the more frequent occur-
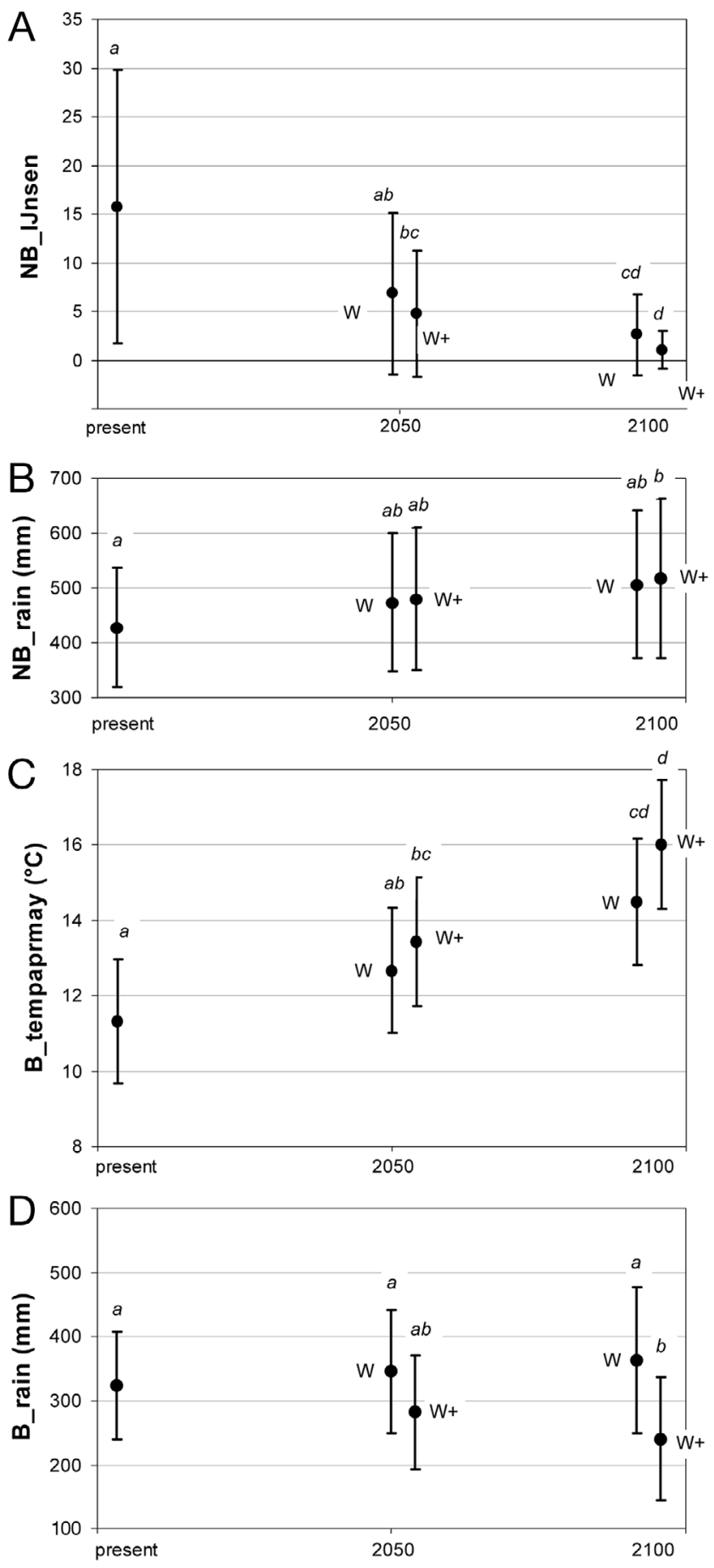

Fig. 4. Weather variable values $( \pm \mathrm{SD})$ for present day (19842004), 2050 (range 2037-2065) and 2100 (range 2087-2115) climate. (A) IJnsen, (B) total precipitation sum over the nonbreeding season, (C) mean temperature from 16 April to 15 May and (D) total precipitation sum over the breeding season; projections for 2050 and 2100 are based on data from KNMI scenarios $\mathrm{W}$ and $\mathrm{W}^{+}$(http://climexp.knmi.nl/Scenarios_monthly/; for explanation of scenarios, see www.knmi.nl/research/climate services/). Within each weather variable, bars sharing the same letter are not significantly different $(p>0.05)$. For abbreviations of weather variables, see Table 2 
Table 4. Species expected to respond most positively and negatively to increased occurrence of mild winters, as indicated by their species-specific regression coefficient $\left(b_{k}\right)$ values. For abbreviations of traits, see Table $1 ; 1$ and 0 denote species that hold or do not hold the trait, respectively. M: marshland species; F: forest species

\begin{tabular}{|c|c|c|c|c|c|c|c|c|c|}
\hline Abbreviation & Species & Common name & lownest & fdpl & altr & resid & fdinvert & migr & habitat \\
\hline \multicolumn{10}{|l|}{ Positive } \\
\hline ACAU & Aegithalos caudatus & Long-tailed tit & 0 & 0 & 1 & 1 & & & $\mathrm{M}, \mathrm{F}$ \\
\hline ACRE & Anas crecca & Teal & 1 & 1 & 0 & 0 & & & $\mathrm{M}$ \\
\hline ASTR & Anas strepera & Gadwall & 1 & 1 & 0 & 0 & & & M \\
\hline BSTE & Botaurus stellaris & Bittern & 1 & 0 & 1 & 1 & & & M \\
\hline COLO & Cygnus olor & Mute swan & 1 & 1 & 0 & 1 & & & M \\
\hline GCHL & Gallinula chloropus & Moorhen & 1 & 0 & 0 & 1 & & & $\mathrm{M}$ \\
\hline LMEG & Luscinia megarhynchos & Nightingale & 0 & 0 & 1 & 0 & & & $\mathrm{M}, \mathrm{F}$ \\
\hline RAQU & Rallus aquaticus & Water rail & 1 & 0 & 0 & 0 & & & $\mathrm{M}$ \\
\hline SATR & Sylvia atricapilla & Blackcap & 0 & 0 & 1 & 0 & & & $\mathrm{M}, \mathrm{F}$ \\
\hline TRUF & Tachybaptus ruficollis & Little grebe & 1 & 0 & 0 & 0 & & & $\mathrm{M}$ \\
\hline \multicolumn{10}{|l|}{ Negative } \\
\hline ECIT & Emberiza citrinella & Yellowhammer & & & & & 1 & 0 & $\mathrm{~F}$ \\
\hline FSUB & Falco subbuteo & Hobby & & & & & 1 & 1 & $\mathrm{~F}$ \\
\hline HICT & Hippolais icterina & Icterine warbler & & & & & 1 & 1 & $\mathrm{~F}$ \\
\hline OORI & Oriolus oriolus & Golden oriole & & & & & 1 & 1 & $\mathrm{~F}$ \\
\hline PCOLL & Phylloscopus collybita & Chiffchaff & & & & & 1 & 1 & $\mathrm{M}, \mathrm{F}$ \\
\hline PSIB & Phylloscopus sibilatrix & Wood warbler & & & & & 1 & 1 & $\mathrm{~F}$ \\
\hline RIGN & Regulus ignicapillus & Firecrest & & & & & 1 & 0 & F \\
\hline SATR & Sylvia atricapilla & Blackcap & & & & & 1 & 1 & $\mathrm{M}, \mathrm{F}$ \\
\hline SBOR & Sylvia borin & Garden warbler & & & & & 1 & 1 & $\mathrm{M}, \mathrm{F}$ \\
\hline SCOM & Sylvia communis & Whitethroat & & & & & 1 & 1 & $\mathrm{M}, \mathrm{F}$ \\
\hline STUR & Streptopelia turtur & Turtle dove & & & & & 0 & 1 & $\mathrm{M}, \mathrm{F}$ \\
\hline TTRO & Troglodytes troglodytes & Winter wren & & & & & 1 & 0 & $\mathrm{M}, \mathrm{F}$ \\
\hline TVIS & Turdus viscivorus & Mistle thrush & & & & & 1 & 0 & $\mathrm{~F}$ \\
\hline
\end{tabular}

rence of mild winters and warm springs will be detrimental to insectivorous long-distance migrants (marshland and forest species) in the Netherlands. Waterfowl species in the Netherlands are expected to profit from the more frequent occurrence of mild winters. It is unclear how the precipitation sum over the non-breeding and breeding seasons will change in the future climate (Fig. 4B,D). For the non-breeding season, the precipitation sum might increase, but this increase is only significant in 2100 under the $\mathrm{W}^{+}$scenario. Under the $\mathrm{W}^{+}$ scenario, the precipitation sum in the breeding season will decrease from the present to 2100, whereas under the W scenario the precipitation sum in 2100 will remain similar to the present sum. Consequently, it is unclear whether species will be harmed by future precipitation.

Based on the species-specific regression coefficients $b_{k}$ resulting from the LTE analyses (Tables S4 \& S5), we identify the species that are expected to respond positively or negatively to a more frequent occurrence of mild winters. Most of the species that are expected to respond positively to climate change, based on their $b_{k}$ values (Table 4) can be characterized as waterfowl (Fig. 3a; among others teal Anas crecca and mute swan Cygnus olor). Most of the species that are expected to respond negatively (Table 4 ) can be characterized as insectivorous long-distance migrants (Fig. 3b; among others icterine warbler Hippolais icterina and golden oriole Oriolus oriolus).

Our results show that the impacts of climate change on species dynamics may interfere with aims set in nature conservation programmes, which often concern the presence and abundance of specific target species in protected areas. Recent studies on ecosystem resilience argue that future nature conservation programmes should focus on the functioning of ecosystems and the distribution of functional groups of species over ecosystems, rather than setting conservation targets on specific rare or declining species (Turner et al. 2007). Species traits play an important role in constructing functional groups that help to understand the relationship between biodiversity and ecosystem functioning. In addition, our study shows that trait analysis also helps to gain insight into the responses of species and functional groups to climate change. In this way, our approach presents a generalized view on the responses of species to weather variability.

Acknowledgements. This research was funded by the Dutch national research programme 'Climate Changes Spatial Planning' and is part of the strategic research programme 'Sustainable spatial development of ecosystems, landscapes, seas and regions' (Project Ecological Resilience) which is funded by the Dutch Ministry of Agriculture, Nature Conservation and Food Quality, and carried out by Wageningen University and 
Research Centre. We thank P. Opdam for helpful comments on the manuscript; M. de Lange for help on Canoco; J. Harms, M. van Oorschot, O. Kostenko and V. Radchuk for their extensive literature searches and data analyses that we used as preparations to our research; and the thousands of observers who gathered breeding bird data in the past decennia - without their efforts this research would not have been possible.

\section{LITERATURE CITED}

Anderson MJ, Legendre P (1999) An empirical comparison of permutation methods for tests of partial regression coefficients in a linear model. J Stat Comput Simulation 62: 271-303

Anderson MJ, Robinson J (2001) Permutation tests for linear models. Aust NZ J Stat 43:75-88

Besbeas P, Freeman SN, Morgan BJT, Catchpole EA (2002) Integrating mark-recapture-recovery and census data to estimate animal abundance and demographic parameters. Biometrics 58:540-547

Bibby CJ (1981) Wintering bitterns in Britain. Br Birds 74:1-10

Bibby CJ, Burgess ND, Hill DA (1997) Bird census techniques. Academic Press, London, UK

Birch LC (1953) Experimental background to the study of the distribution and abundance of insects. I. The influence of temperature, moisture and food on the innate capacity for increase of three grain beetles. Ecology 34:698-711

Bolger DT, Patten MA, Bostock DC (2005) Avian reproductive failure in response to an extreme climatic event. Oecologia 142:398-406

Both C, Visser ME (2001) Adjustment to climate change is constrained by arrival date in a long-distance migrant bird. Nature 411:296-298

Both C, Visser ME (2005) The effect of climate change on the correlation between avian life-history traits. Glob Change Biol 11:1606-1613

Both C, Bouwhuis S, Lessells CM, Visser ME (2006) Climate change and population declines in a long-distance migratory bird. Nature 441:81-83

Both C, van Asch M, Bijlsma RG, van den Burg AB, Visser ME (2009) Climate change and unequal phenological changes across four trophic levels: constraints or adaptations? J Anim Ecol 78:73-83

Both C, Van Turnhout CAM, Bijlsma RG, Siepel H, Van Strien AJ, Foppen RPB (2010) Avian population consequences of climate change are most severe for long-distance migrants in seasonal habitats. Proc R Soc Lond B 277:1259-1266

Brown CR, Brown MB (1998) Intense natural selection on body size and wing and tail asymmetry in cliff swallows during severe weather. Evolution 52:1461-1475

Cramp S, Simmons KEL (1977-1994) Handbook of the birds of Europe, the Middle East and North Africa: the birds of the Western Paleartic. Oxford University Press, Oxford

Den Held JJ (1981) Population changes in the purple heron in relation to drought in the wintering area. Ardea 69: 185-191

Dolédec S, Statzner B, Bournard M (1999) Species traits for future biomonitoring across ecoregions: patterns along a human-impacted river. Freshw Biol 42:737-758

Dray S, Legendre P (2008) Testing the species traits-environment relationships: the fourth-corner problem revisited. Ecology 89:3400-3412

EU (2009) Adapting to climate change: towards a European framework for action \{SEC(2009) 386\} \{SEC(2009) 387\} \{SEC(2009) 388\}. Commission of the European Communities, Brussels
Foppen R, ter Braak CJF, Verboom J, Reijnen R (1999) Dutch sedge warblers Acrocephalus schoenobaenus and WestAfrican rainfall: empirical data and simulation modelling show low population resilience in fragmented marshlands. Ardea 87:113-127

Ihaka R, Gentleman R (1996) R package. http://cran.r-project. org

IJnsen F (1981) Onderzoek naar het optreden van winterweer in Nederland (in Dutch). Royal Netherlands Meteorological Institute (KNMI), De Bilt

IPCC (2001) Climate change 2001: impacts, adaptations and vulnerability. Contribution of Working Group II to the Third Assessment Report of the Intergovernmental Panel on Climate Change [McCarthy JJ, Canziani OF, Leary NA, Dokken DJ, White KS (eds)]. Cambridge University Press, Cambridge

IPCC (2007) Climate change 2007: synthesis report. Contribution of Working Groups I, II and III to the Fourth Assessment Report of the Intergovernmental Panel on Climate Change [Core Writing Team, Pachauri RK, Reisinger A (eds)]. IPCC, Geneva

Jiguet $F$, Julliard R, Thomas CD, Dehorter O, Newson SE, Couvet D (2006) Thermal range predicts bird population resilience to extreme high temperatures. Ecol Lett 9: 1321-1330

Jones J, Doran PJ, Holmes RT (2003) Climate and food synchronize regional forest bird abundances. Ecology 84: 3024-3032

Karlsson B, Van Dyck H (2005) Does habitat fragmentation affect temperature-related life-history traits? A laboratory test with a woodland butterfly. Proc R Soc Lond B 272: 1257-1263

Karlsson B, Wiklund C (2005) Butterfly life history and temperature adaptations; dry open habitats select for increased fecundity and longevity. J Anim Ecol 74:99-104

Keddy PA (1992) Assembly and response rules: two goals for predictive community ecology. J Veg Sci 3:157-164

Legendre P, Galzin R, Harmelin-Vivien ML (1997) Relating behavior to habitat: solutions to the fourth-corner problem. Ecology 78:547-562

Lemoine N, Schaefer HC, Bohning-Gaese K (2007) Species richness of migratory birds is influenced by global climate change. Glob Ecol Biogeogr 16:55-64

Meehl GA, Tebaldi C (2004) More intense, more frequent, and longer lasting heat waves in the 21st century. Science 305:994-997

Møller AP, Rubolini D, Lehikoinen E (2008) Populations of migratory bird species that did not show a phenological response to climate change are declining. Proc Natl Acad Sci USA 105:16195-16200

Morgan R, Glue D (1977) Breeding, mortality and movements of kingfishers. Bird Study 24:15-24

Newton I (1998) Population limitation in birds. Academic Press, San Diego

Newton I (2004) Population limitation in migrants. Ibis 146: 197-226

- Norris DR, Taylor CM (2006) Predicting the consequences of carry-over effects for migratory populations. Biol Lett 2: 148-151

Pannekoek J, Van Strien AJ (2005) TRIM 3 manual (TRends \& Indices for Monitoring Data). Statistics Netherlands, Voorburg, The Netherlands

> Peach W, Dufeu C, Mcmeeking J (1995) Site-tenacity and survival rates of wrens Troglodytes troglodytes and treecreepers Certhia familiaris in a Nottinghamshire wood. Ibis 137:497-507

Ranta E, Lundberg P, Kaitala V, Laakso J (2000) Visibility of 
the environmental noise modulating population dynamics. Proc R Soc Lond B 267:1851-1856

Robinson RA, Baillie SR, Crick HQP (2007) Weather-dependent survival: implications of climate change for passerine population processes. Ibis 149:357-364

Sæther BE, Tufto J, Engen S, Jerstad K, Rostad OW, Skatan JE (2000) Population dynamical consequences of climate change for a small temperate songbird. Science 287: 854-856

Sæther BE, Sutherland WJ, Engen S (2004) Climate influences on avian population dynamics. Adv Ecol Res 35:185-209

Sanderson FJ, Donald PF, Pain DJ, Burfield IJ, van Bommel FPJ (2006) Long-term population declines in AfroPalearctic migrant birds. Biol Conserv 131:93-105

Sparks TH, Crick HQP, Elkins N, Moss R, Moss S, Mylne K (2002) Birds, weather and climate. Weather 57:399-410

Speek BJ, Speek G (1984) Thieme's trekvogelatlas. Thieme, Zutphen, The Netherlands

Stoutjesdijk P, Barkman JJ (1992) Microclimate, vegetation and fauna. Opulus Press, Knivsta, Sweden

Takane Y, Hunter MA (2001) Constrained principal component analysis: a comprehensive theory. Appl Algebra Eng Commun Comput 12:391-419

Takane Y, Yanai H, Mayekawa S (1991) Relationships among several methods of linearly constrained correspondence analysis. Psychometrika 56:667-684

Ter Braak CJF, Prentice IC (1988) A theory of gradient analysis. Adv Ecol Res 18:271-317

Ter Braak CJF, Šmilauer P (2002) CANOCO reference manual and CanoDraw for Windows user's guide: software for canonical community ordination (version 4.5). Microcomputer Power, Ithaca

Editorial responsibility: Nils Chr. Stenseth, Oslo, Norway
Turner WR, Brandon K, Brooks TM, Costanza R, da Fonseca GAB, Portela R (2007) Global conservation of biodiversity and ecosystem services. Bioscience 57:868-873

van den Dool HM, Nap JL (1981) An explanation of persistence in monthly mean temperatures in the Netherlands. Tellus 33:123-131

Van Dijk AJ (2004) Handleiding Broedvogel Monitoring Project. SOVON Vogelonderzoek Nederland, Beek-Ubbergen, The Netherlands

Van Dijk AJ, Hustings F, Van der Weide M (2004) Handleiding Landelijk Soortonderzoek Broedvogels. SOVON Vogelonderzoek Nederland, Beek-Ubbergen, The Netherlands

- Van Oldenborgh GJ, Van Ulden A (2003) On the relationship between global warming, local warming in the Netherlands and changes in circulation in the 20th century. Int $\mathrm{J}$ Climatol 23:1711-1724

> Van Turnhout CAM, Foppen RPB, Leuven RSEW, Van Strien A, Siepel H (2010) Life-history and ecological correlates of population change in Dutch breeding birds. Biol Conserv 143:173-181

Wernham CV, Toms MP, Marchant JH, Clark JA, Siriwardena GM, Baillie SR (eds) (2002) The migration atlas: movement of the birds of Britain and Ireland. T. \& A.D. Poyser, London

Wolff WJ (1993) Netherlands-wetlands. Hydrobiologia 265: $1-14$

Wunderle JM, Lodge DJ, Waide RB (1992) Short-term effects of hurricane Gilbert on terrestrial bird populations on Jamaica. Auk 109:148-166

Zwarts L, Bijlsma RG, Van der Kamp J, Wymenga E (2009) Living on the edge: wetlands and birds in a changing Sahel. KNNV Uitgeverij, Zeist, the Netherlands

Submitted: October 11, 2010; Accepted: April 9, 2011

Proofs received from author(s): August 4, 2011 